\title{
Satisfaction among accounting professors in Brazil
}

\author{
Tamires Sousa Araújo \\ Universidade Federal de Uberlândia, Faculdade de Ciências Contábeis, Uberlândia, MG, Brazil
}

\section{Gilberto José Miranda}

Universidade Federal de Uberlândia, Façuldade de Ciências Contábeis, Programa de Pós-Graduação em Ciências Contábeis, Uberlândia, MG, Brazil

\section{Janser Moura Pereira}

Universidade Federal de Uberlândia, Faculdade de Matemática, Uberlândia, MG, Brazil

Received on 03.18.2016 - Desk acceptance on 04.10.2016 - $5^{\text {th }}$ version approved on 02.12.2017

\begin{abstract}
The aim of this study was to identify the prevalence of satisfaction among accounting professors in Brazil throughout their careers. The research is classified as descriptive and used a quantitative approach to data analysis. 641 valid responses were obtained from professors from all regions of Brazil. The results show that a feeling of satisfaction prevails among accounting course professors, as most of them "like the profession" and, in general, "are satisfied with it". It was found that levels of satisfaction are higher among individuals with more experience, in that in their first years in the job (one to three years), professors have lower satisfaction rates; the highest levels of satisfaction are found in the final stage (over 35 years). The main factor that influences satisfaction is personal fulfillment (teaching work and relationship with students). It was also . possible to identify that positive feelings about teaching predominate $(67.3 \%)$ compared to negative ones (32.7\%). These results show the need for greater attention to be paid in the early years of the career in order to avoid a "reality clash". They also show the need for other studies to investigate how the phases in the life cycle of accounting professors are characterized.
\end{abstract}

Keywords: teaching, professional qualification, accounting professors, accounting, higher education. 


\section{INTRODUCTION}

Job satisfaction is a relevant topic when thinking about professional development in any area, including education. However, little is known about the levels of satisfaction, the factors associated with it, and the predominant feelings among professors in higher education. Recent changes make the topic even more important.

The approval of Act n. 9,394/1996 - Law of Guidelines and Bases for National Education (Brazil, 1996) - enabled big changes in Brazilian higher education. The number of positions in public and private teaching increased, new modalities appeared, such as distance learning, and mechanisms were constructed for regulating quality, aimed at assessing and monitoring educational policies.

In the 1980s, matriculations in higher education numbered approximately 300 thousand. In 2013, the Census on Higher Education indicated 7,305,977 matriculated students; of these, $74 \%$ were in private institutions and 26\% were in public ones (Anísio Teixeira National Institute for Educational Studies and Research [INEP], 2013). This story was no different in accounting courses. In 1991 there were approximately 97 thousand students matriculated. In 2013, this number had increased to 328,031 students. In 2013, accounting courses came to occupy fourth position in number of matriculations in Brazilian higher education, with approximately $4.5 \%$ of total matriculations.

However, accounting courses have successively presented low academic performance indices, both in the National Student Performance Exam (ENADE) and in the Sufficiency Exam promoted by the Federal Council for Accounting (CFC). The results from the ENADE in the 2006, 2009, and 2012 editions were around 34\%, with accounting thus featuring among the worst performing courses. Similarly, between the first edition of the 2011 Sufficiency Exam and the first one from 2015, average candidate performance was $43 \%$ (Federal Council for Accounting, 2015).

Against this backdrop, professors face the challenge of remaining up to date, of understanding student diversity, and of diversifying with regards to forms of teaching, in order to have a better chance of reaching the heterogeneity present in the classroom, and thus fulfill their role in the teaching-learning process.

Moreover, studies are needed that include the role of teaching staff in the process of training future professionals, as well as factors that can affect their job satisfaction. This investigation was therefore guided by the following question: how prevalent is satisfaction among accounting professors in Brazil throughout their careers?

Job satisfaction can be defined as a sensitive feeling that results from analyzing the work environment and experiences within it (Ferreira, 2011). Ramos (2009) indicates that job satisfaction can be understood as a positive emotional state derived from a profession. Freitas (2011) understands that satisfaction is a base-component for any organization and that it supports the development of institutions.

One of the main theories related with job satisfaction is the two-factor theory proposed by Herzberg (1987), which was based on the theory of human motivation from Maslow (1943). Herzberg (1987) proposes that satisfaction is motivated by "job enrichment", which means offering opportunities for the psychological growth of employees, thus keeping them satisfied with their work. Pedro and Peixoto (2006) justify the use of this theory in the educational environment due to it being directly solely towards job satisfaction, with it being able to efficiently measure whether teaching staff are satisfied with their organizational environment or not. This environment covers all of the important components in an organization, such as working conditions and economic and political relationships (Megginson, Mosley \& Pietri, 1986).

Studies carried out by different authors based on the theory from Herzberg (1987) and with regards to elementary level education in Portugal have shown that job satisfaction among teachers is low, that teacher malaise is persistent, and that this evidence could affect student performance (Jesus, Abreu, Santos \& Pereira, 1992; Pedro \& Peixoto, 2006). In Brazil, a few studies on higher education show greater levels of satisfaction (Assunção, Domingos, Cabral, Santos \& Pessoa, 2014; Moretti, 2010; Traldi \& Fiuza, 2012).

In the area of accounting, these studies are rare. However, understanding the prevalence of satisfaction among accounting professors throughout their careers could contribute with observations about institutional actions for improving the work environment and favoring the professional training process.

Besides this introduction, this article contains three sections. In the second section the theories related to job satisfaction are presented, with an emphasis on the theory from Herzberg (1987) and the life stages of 
teaching professionals, and focusing on Huberman (2000). In the third section the methodological procedures are presented: data collection, composition of the instrument, sample, and statistical tests used. In the fourth section the results are presented: descriptive statistics, satisfaction scores in each life cycle stage, factors identified, and feelings experienced by the professors. Finally, in the fifth section, the final remarks are presented.

\section{A LOOK AT JOB SATISFACTION AMONG PROFESSORS}

For Ferreira (2011, p. 16), "since the first decades of the twentieth century, man's satisfaction at work has constituted a factor of growing concern", as it can be understood that lack of job satisfaction can cause worker frustration and losses to employers and those who receive the services provided.

Bergamini (1997) shows that it is common in many organizations for there to be workers who are unsatisfied with what they do and who are only in the company for the remuneration that they use to be happy outside of work, which makes satisfaction a problem for both sides, employee and employer. According to Ferreira (2011), the reason for such concern is that this lack of satisfaction can cause disharmony in the work environment, reducing productivity.

In conceptual terms, Anitha (2011) indicates that job satisfaction is a general attitude regarding how much employees like their jobs, with this satisfaction being important to the total quality of an organization, since it enables higher employee and employer performance. For Ferreira (2011, p. 74), being satisfied in the organizational environment can be understood as "a pleasant or positive emotional state resulting from the evaluation of some job or experiences in the job". The author also adds that:

(...) job satisfaction is a pleasurable emotional state derived from evaluating a job with regards to an individual's values, related to the job. Job dissatisfaction is an unpleasant emotional state derived from evaluating a job as ignoring, frustrating, or denying the individual's values, related to the job (Ferreira, 2011, p. 74 apud Locke, 1976).

Many authors indicate job satisfaction as a "positive" employee state with regards to their job (Alves, 1991, 1994; Gursel, Sunbul \& Sari, 2002; Seco, 2000). Others address satisfaction as professional success (Frase \& Sorenson, 1992; Jesus, 1993, 1995; Pinto, 1996; Sánchez \& García, 1997). All of these approaches show that job satisfaction is linked to the situation in which workers find themselves in companies, and whether they consider themselves to be "happy" with the role that they carry out and how much they are valued.

A pioneering study on the topic of job satisfaction was conducted by Maslow (1943), establishing the foundations of the theory of human motivation. According to Maslow, human needs present a pyramidal hierarchy in which the lowest level (the base of the pyramid) is composed of the most basic (physiological) needs, while the other levels (security needs, social, self-esteem, and self-fulfillment needs) become more difficult to reach as the pyramid is climbed. Following on from this reasoning, Bohrer (1981, p. 44) highlights that "individuals will only be motivated by a higher level of needs when they have satisfactorily achieved the previous levels".

Thus, any threat to these needs can cause frustrations in an individual. Maslow (1943) explains that a frustrated man can be considered as a sick individual. The author contemplates that it is the task of organizations to create a bridge between basic needs and worker fulfillment in a company.

Following on from this, Ferreira, Demutti, and Gimenez (2010, p. 7) highlight that "even if all basic needs are at least partially satisfied, individuals can feel unhappy if they are not using their full ability". Also according to these authors, another weakness in the theory is the rigidity of the levels, since in order for an individual to reach higher levels the lower ones need to be totally satisfied. However, this often does not occur. Sometimes a person can aspire to a need from higher levels even without fully satisfying the lower levels. Bergamini (1997) adds that the research developed by Maslow lacked empirical support, with no test that validated it in practice, given that it was carried out via observations.

Despite the criticisms, the theory from Maslow (1943) provided support to others, such as the two-factor theory (Ferreira et al., 2010) proposed by Herzberg (1987), which highlights that the basic needs presented by Maslow (1943) do not create motivation, but rather "movement". Basically, the movement would be all of the attitudes taken by an organization (such as increasing salaries, bonuses, benefits, changing roles, etc.) that make individuals carry out certain tasks. These are what Herzberg (1987) called extrinsic factors.

Developed for the context of professional work, the theory from Herzberg (1987) establishes that satisfaction is driven by "job enrichment", which would be offering opportunities for the psychological growth of employees. 
In order to satisfy workers, it is necessary to fulfill their esteem and self-fulfillment needs. Enrichment can occur via the type of work or with increases in the range of

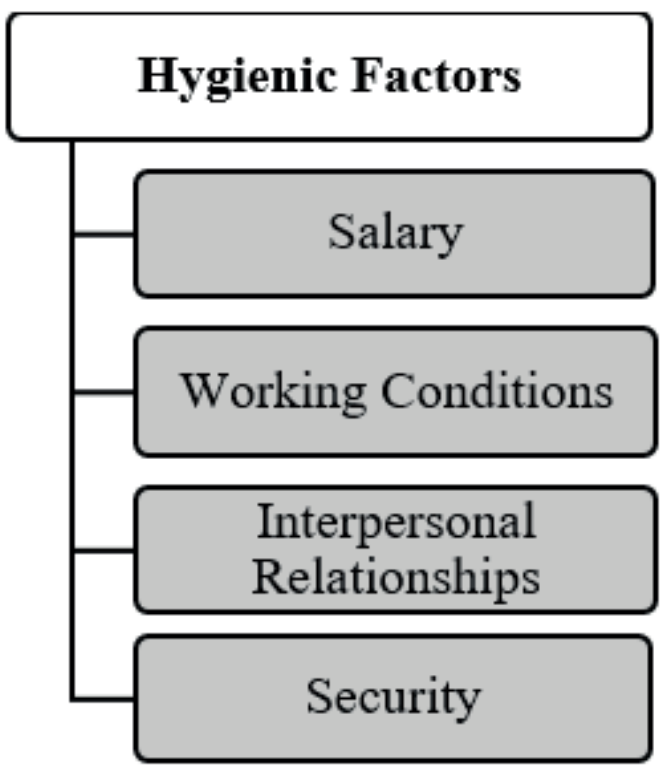

Figure 1 Hygienic and motivational factors: Herzberg Theory Source: Hering (1996).

For Herzberg (1987), the hygienic factors are extrinsic and prevent dissatisfaction, but the employee has no control over them. Moreover, these factors feature in the analysis of variables that are beyond the work, involving what is external for individuals (salary, security, etc.), and what is within the environment they coexist in. Bergamini (1997) states that increasing salary or rewards raises the level of productivity in the short run, but this increase does not last.

A lack of hygienic factors can demotivate workers, such as when an employee does not think their remuneration is sufficient, the working conditions are not good, the interpersonal relationships between colleagues and leadership are not good, there is uncertainty about their employment within some months, etc. These hygienic factors only inhibit dissatisfaction for a limited period of time and do not create motivation. Bergamini (1997) adds that the more money is involved in rewards, the greater the damage to the company can be if these values are removed from the workers, since they can understand this as a punishment, which can result in major conflicts and dissatisfaction.

As for the intrinsic motivational factors, these create satisfaction among employees and can, for a longer period work. Herzberg (1987) presents two groups of factors for motivation at work: hygienic factors and motivational factors, which are illustrated in Figure 1.

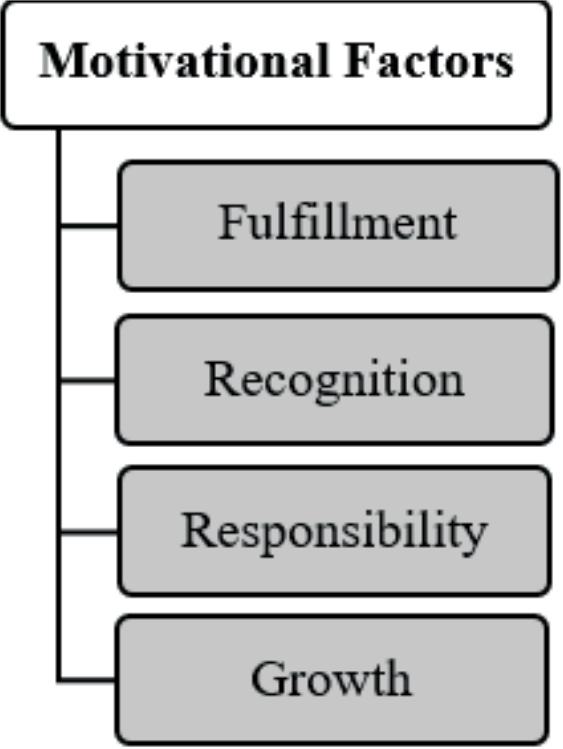

of time, "control" employee dissatisfaction. These factors are directly related to the employee's function, since he/ she can feel more satisfied by having more responsibilities staff (Herzberg, 1987). For the author, some activities in organizations can motivate workers, including: freedom in their role, accountability for their own work, and more authority being given to them. However, not all organizations and not all jobs can be enriched.

Pedro and Peixoto (2006), supported by the theory from Herzberg (1987), carried out a study aiming to analyze the job satisfaction index of teachers in elementary cycles 2 and 3 in Portugal. The results from the research indicate an average job satisfaction index of 2.34, on a scale of 5 points. The "sociopolitical dimension" factor, related to items concerning salary and professional questions, was the most strongly associated with dissatisfaction, with the "teacher salary", "attitude of parents and society towards teachers", "students' behavior in class", "security and stability at work", and "processes for career progression" variables standing out.

The authors also analyzed the relationship between the teacher life cycle and job satisfaction and identified that the group with between 7 and 15 years in teaching present a higher satisfaction value (3.15 points) and that 
the new teachers in the first group with 1 to 6 years present a lower value (2.21 points).

In Brazil, Taveira and Silva (2015) studied the relationship between job satisfaction among teachers and the performance presented by students in the Prova Brasil (National School Performance Evaluation) in the city of Macaé, in the state of Rio de Janeiro. The study involved 77 teachers at 6 elementary education institutions. In order to carry it out, the Siqueira (2008) questionnaire - Job Satisfaction Scale (JSS) - was used to identify satisfaction among the teachers. The results prove that there is a positive correlation between satisfaction and student performance in the Prova Brasil. Using a 7 point scale, the study also showed the following satisfaction indices: 3.90 and 3.16 points in relation to salaries, 3.36 and 3.17 points in relation to promotion, 4.20 and 4.90 points in relation to leadership, 4.18 and 4.27 points in relation to the nature of the work, and 5.11 and 5.19 points in relation to work colleagues.

Traldi and Fiuza (2012) carried out a study aimed at identifying the levels of organizational commitment, wellbeing, and satisfaction among 76 professors who lectured in at least one subject to business course students at a university. The results regarding job satisfaction indicate that, on a scale of 0 to 5 points, the professors were satisfied with the "leadership" (4.23 points), with the "colleagues" (4.02 points), and with the "nature of the work" (3.42). The authors explain the relatively high results as being due to the arrival of new management at the university, which invested in improvements in the environment and in working conditions. The results indicate that the greater the effective commitment of the professionals, the greater the levels of well-being and satisfaction.

Moretti (2010) aimed to identify the profile and level of job satisfaction of business course professors at private teaching institutions in the city of Ribeirão Preto, in the state of São Paulo, using the JSS tool. The sample was composed of 127 answered questionnaires. The author analyzed the following factors related to satisfaction: colleagues, salary, leadership, nature of work, and promotions. The authors emphasize that, in general, the professors were satisfied with their colleagues (5.51), leadership (5.48), and the nature of the work (5.23), but dissatisfied with salary (3.94) and promotions (3.85), on a scale of 1 to 7 points. The authors also report that in relation to job satisfaction there is no significant difference between genders. It was also shown that salary increases do not affect levels of satisfaction.

Assunção et al. (2014) analyzed the relationship between the level of satisfaction and level of affective organizational commitment of accounting course university professors. The sample was composed of 42 professors from two universities (Federal University of Ceará and University of Fortaleza), corresponding to $65 \%$ of the accounting course professors. Using the Mann Whitney $U$ test, they investigated the variables work, relationships, salary, outlook, and autonomy. The results revealed that there is a positive and moderate relationship between job satisfaction and effective organizational commitment. It was also shown that the "salary" and "autonomy" variables were not significant and are not related with the level of professor satisfaction. As for the "work" and "skills and relationships" variables, these are factors that presented a positive relationship with satisfaction, being linked to professor satisfaction. It was also found that there was no significant difference in satisfaction between the public and private university professors studied (Assunção et al., 2014).

Thus, by carrying out a broad diagnosis of the satisfaction prevalent among accounting course professors in Brazil, as well as its evolution throughout their careers, this study fills some gaps. Understanding the path professors traverse over the course of their careers has been the topic of studies by a number of authors (Araújo, Lima, Oliveira \& Miranda, 2015; Gonçalves, 1995, 2009; Huberman, 1989, 2000; Jesus \& Santos, 2004; Lima, Oliveira, Araújo \& Miranda, 2015; Veenman, 1984).

A classical study concerning the topic was developed by Huberman $(1989,2000)$, the aim of which was to identify the stages traversed by teachers during their careers. The investigation was carried out using elementary cycle teachers. A teacher's life cycle begins in the career entry stage, which lasts from one to three years. In this stage, two factors are important: the "discovery" aspect, "which translates initial enthusiasm, experimentation, and exaltation from finally being in a position of responsibility", and "survival", in which a "reality shock" can be present, since in this period teachers will find themselves in the classroom, which may enter into conflict with all of their "beliefs" and expectations from before beginning their career (Huberman, 2000, p. 39).

The second stage revealed by the study from Huberman (2000) is the establishment stage, which involves a time of choice in which the teacher commits definitively to the profession. Its duration is from four to six years in the job. It can be noted that in this stage professionals tend to ensure their place in the job, acquire their qualifications, and occupy administrative roles, thus increasing their responsibilities at an institution. 
The third stage established by Huberman (2000) is that of diversification or questioning (self-questioning), this being the longest life cycle stage. This stage begins after seven years in teaching and extends up to 25 years. Huberman (2000, p. 41) affirms that, in the diversification stage, "people then embark on a small series of personal experiments, diversifying didactic material, evaluation methods, the way students are grouped, the sequence of programs, etc.. However, after leaving the establishment stage, a teacher may, instead of entering the diversification stage, go on to the questioning stage. The symptoms of this stage range "from a mild sensation of routine to an existential 'crisis' regarding career fulfillment" (Huberman, 2000 , p. 42). Also in this stage, teachers carry out an analysis of their life and their career, questioning their goals and objectives to be achieved.

The fourth stage will depend on the path taken in the previous stage. If a teacher underwent diversification, in the fourth stage he/she will enter into serenity, which is characterized by a gradual distancing from the students, which occurs peacefully (Huberman, 2000). On the other hand, if the teacher has previously experienced questioning, in this career stage he/she will undoubtedly experience conservatism, when the professional feels anxious, dissatisfied, regretful about life and career, and resistant to changes. The duration of this stage ranges from 25 to 35 years in a career (Huberman, 2000).

After all of these stages, a final, divestment stage begins. Ferreira (2008, p. 33) understands this stage to be "a phenomenon that can be seen as a 'divestment' in personal and institutional plans, a retreat from the ambitions or ideas present at the beginning." For Huberman (2000, p. 50) "it is a time when people view their own lives as 'inevitable', as one life that 'had to' happen the way it did and that needs to be accepted as such". In this stage, considered to be the end of a teaching career, the divestment process and departure from the career begins.

As verified, the path of a teaching career is not a sequence of events, but rather a process (Huberman, 2000) that starts in post-graduation, when the initial teacher training beings (or should), and extends until the career ends.

Pedro and Peixoto (2006) indicate that the life stages can be related with teacher motivation, since in certain stages addressed by Huberman (2000), teachers can be more or less demotivated. With regards to this, the studies from Araújo et al. (2015) and Lima et al. (2015) reveal that, in the field of accounting courses in Brazil, the initial stage in the teaching profession has been the most problematic, affected mainly by student demotivation, heterogeneous class, the amount of administrative work, very numerous classrooms, and lack of time.

It is therefore understood that this paper is different from those previously discussed, since it aims to identify the prevalence of satisfaction among accounting professors in Brazil throughout their careers. By addressing this gap, it can provide relevant contributions to the literature and to teaching in the area of accounting.

\section{METHODOLOGICAL ASPECTS}

This study is descriptive and aims to identify the prevalence of satisfaction among accounting professors in Brazil over the course of their careers. The approach to the research problem is quantitative. The data were gathered using the questionnaire tested and validated by Pedro and Peixoto (2006), in which some adjustments were made after observing the reality of accounting teaching in Brazil, such as the insertion of the terms "accounting professor" and "teaching activity", and the scale was changed, adopting scores from 1 to 10 . These changes were needed in order to use the tool in the context of higher education in accounting, as well as to apply exploratory factor analysis (EFA), as suggested by Fávero, Belfiore, Silva, and Chan (2009). The final version was approved by the Ethics Committee of the Federal University of Uberlandia.

The questionnaire was divided into four sections: 
1) characterization of the respondents (gender, age, time teaching, qualification, region of origin, type of institution);

2) general level of satisfaction (with four statements to which the participants should respond on a scale ranging from "completely disagree" to "completely agree", with values close to 1 for disagree and close to 10 for agree);

3) factors related with satisfaction, which are based on the two-factor theory - hygienic and motivational;

4) feelings perceived in teaching, with the option to choose three feelings experienced in teaching out of 12 feelings presented ( 6 positive and 6 negative).

For the data collection a database of the possible respondents was created. This process was carried out in three stages. First, all of the institutions that offered accounting courses in Brazil were identified. This investigation was carried out using the e-MEC platform (http://emec.mec.gov.br/), an electronic system for monitoring higher education processes in which there is information on course recognition, authorization, etc. The platform offers a list of all of the institutions and all of the courses registered. Using an advanced search (accounting science courses in operation in Brazil), it was possible to obtain a spreadsheet of 1,292 courses.

In the second stage, the websites of the institutions listed in the spreadsheet obtained using the e-MEC platform were visited. The database was composed of different information, such as: name of institution, institution website, name of course coordinator, email address of the course coordinator, and email addresses of professors linked to the institution (this information was predominantly made available in public institutions). The searches resulted in a total of 1,706 course coordinator and 2,849 professor email addresses.

Subsequently, the data collection tool was stored in the Google Docs platform, were it remained available between May 26 and July 26 of 2015, when the invitations were sent to the participants. These were sent in two ways: first, electronic messages were sent to the course coordinators requesting that they respond to the survey and pass on the message to the other professors in their respective institutions. Then individual messages were sent to the 2,849 professors previously identified. The messages were sent by electronic direct mail, specifying the name of the professors.

Gall, Gall, and Borg (2007) highlight that a recurring problem with the use of questionnaires for capturing data is reply rate, which is considered low. In this case, the electronic messages were sent three times, making different appeals (e.g. the relevance of the research to teaching, a commitment to get back with the results, and mentioning the low rate of replies to previous mailings), since, according to the authors, this procedure increases the reply rate. The mailing was carried out with 20 intervals in between. In this period, 652 replies were received, and of this total, 11 respondents did not agree to take part in the study or left the questionnaire blank. Thus, the final sample was composed of 641 replies.

After receiving the replies, the data analysis began, which was carried out in three stages: in the first, the descriptive statistics of the sample were carried out (gender, age, time teaching, qualification, region of origin, and type of institution). In the second stage, multiple comparisons of proportions tests were conducted to compare the proportions of satisfaction and dissatisfaction among the professors in the sample (tables 2 and 5), as well as the test of the association between level of satisfaction and stage. The $\mathrm{p}$-values from the tests of association are presented in figures $2,4,5$, and 6 . Both tests follow a chi-squared distribution.

For comparing two proportions or more, Biase and Ferreira (2009) recommend the chi-squared test of asymptotic multiple comparisons of binominal proportions, since this test presents reliable results and does not depend on assumptions (additivity, independence of observations, residual normality, homogeneity of variances). The chi-squared test of independence (or association) assumes that: (i) no cell in the table has an expected frequency of less than 1 and (ii) no more than $20 \%$ of the cells have an expected frequency of less than 5. Non-verification of the assumptions leads to resorting to Monte Carlo simulations. Therefore, in this paper, the chi-squared test based on Monte Carlo sampling was applied $(\mathrm{n}=10,000)$ (Siegel \& Castellan, 1988).

In the third stage, EFA was carried out to group, into factors, the questions from section 3 of the questionnaire. EFA aims to explain the correlation or covariance in a group of variables. The factorial test enables how much each factor is associated to each variable to be assessed, as well as analyzing how much the factors found explain the variability of the results obtained using the sum of variances in the original variables (Fávero et al., 2009).

Also, according to Fávero et al. (2009, p. 237), in order to apply factor analysis, the sample should have "at least 5 times more observations than the number of variables that compose the database". As a sample of 641 respondents was obtained and the questionnaire had 25 items, the sample has 25.64 times the number of items, thus satisfying this assumption. Finally, in order to analyze the level of reliability of the data collection tool and of the 
factors assessed, Cronbach's alpha was used, presented on the last line of Table 3, as suggested by Hair, Anderson, Tatham, and Black (2005).

In order to verify whether there is any correlation between the factors found in the factor analysis and the variables related to general satisfaction among the professors, correlation coefficients were used, which according to Martins and Teófilo (2007) indicate the strength of a connection between two variables, which is shown in Table 4. Considering that the data did not present normality, the Spearmen non-parametric correlation test was used.
It bears mentioning that the term "correlation" only enables affirmations to be made about associations and never about cause and effect, since it is not possible to directly observe the effect of one factor, as the same individual cannot, at the same time, be exposed and not exposed to the factor. In reality, what is observed are two groups, one which is exposed to the factor and another which is not. Thus, by using these groups it is possible to identify the connection by means of measurements such as correlation coefficients.

\section{RESULTS ANALYSIS}

First, the profile of the respondents is presented. This aspect is important, since previous studies have addressed different audiences from that of this study. The sample was composed of 641 accounting science professors in Brazil, as shown in Table 1.

Table 1 Profile of respondents

\begin{tabular}{|c|c|c|c|}
\hline Variables & & Total & $\%$ \\
\hline General sample & & 641 & 100 \\
\hline \multirow{2}{*}{ Gender } & Female & 236 & 36.8 \\
\hline & Male & 405 & 63.2 \\
\hline \multirow{5}{*}{$\begin{array}{l}\text { Stages } \\
\text { (years) }\end{array}$} & Up to 3 & 56 & 8.7 \\
\hline & $4-6$ & 112 & 17.5 \\
\hline & $7-25$ & 402 & 62.7 \\
\hline & $26-35$ & 54 & 8.4 \\
\hline & More than 35 & 17 & 2.7 \\
\hline \multirow{5}{*}{ Qualification } & Graduation & 03 & 0.5 \\
\hline & Specialization & 71 & 11.1 \\
\hline & Master's & 323 & 50.4 \\
\hline & Doctorate & 238 & 37.1 \\
\hline & Post-Doctorate & 06 & 0.9 \\
\hline \multirow{6}{*}{ Region } & Central-West & 65 & 10.1 \\
\hline & Northeast & 117 & 18.3 \\
\hline & North & 28 & 4.4 \\
\hline & Southeast & 218 & 34 \\
\hline & South & 205 & 32 \\
\hline & No answer & 08 & 1.2 \\
\hline \multirow{3}{*}{ Insitution } & Public & 374 & 58.3 \\
\hline & Private & 229 & 35.7 \\
\hline & Both & 38 & 5.9 \\
\hline
\end{tabular}

Source: Developed by the authors.

The respondent profile is composed of $63.2 \%$ male and $36.8 \%$ female professors. Although males are predominant in the sample, a growing entry of women into the initial stages of the teaching career in accounting can be noticed, with an inversion occurring in the predominant gender among new arrivals, as shown in Figure 2. This result supports the trend identified by Araújo et al. (2015). 


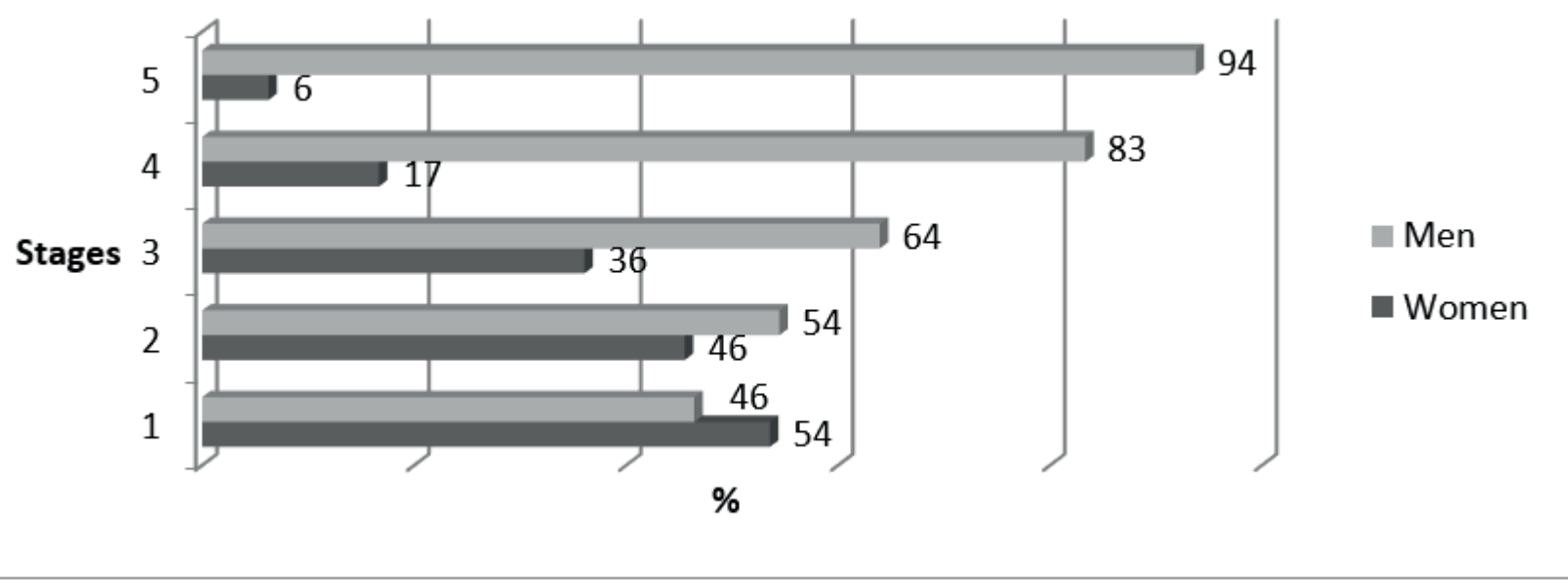

Figure 2 Gender per life cycle stage Source: Developed by the authors.

With regards to time in teaching, analyzed in accordance with the professional life cycle stages proposed by Huberman (2000), it was verified that $8.7 \%$ of the sample are new arrivals to the career, as they have been teaching for up to 3 years, $17.5 \%$ are professors in the establishment stage of their careers, with 4 to 6 years of teaching experience, the majority of the professors investigated, $62.7 \%$, are passing through the intermediate stage, with 7 to 25 years in teaching, $8.4 \%$ have between 26 and 35 years of experience, and $2.7 \%$ are in the stage known by Huberman (2000) as divestment, with more than 35 years in teaching.

In relation to the respondents' qualifications, a prevalence of masters is observed, covering $50.4 \%$ of the total, followed by doctors, (or post-doctors), with $38 \%$, and specialists, representing $11.6 \%$ of the participants. It was interesting to observe that $88.4 \%$ of the sample has a strict sensu qualification, which may be associated with the greater number of respondents from public institutions (58.3\%).

With a greater number of institutions having a higher course in accounting, the Southeast also presented the greatest number of replies (34\%), followed by the South region, with $32 \%$. The Northeast presented $18.3 \%$, the Central-West region presented $10.1 \%$, and the North region represented $5.9 \%$ of total respondents.

It was also identified that $58.3 \%$ of the professors lectured at public higher education institutions (HEIs), $35.7 \%$ at private HEIs, and $4.4 \%$ worked at HEIs of both types. These results are not consistent with the proportions of matriculations in public and private HEIs in Brazil, since the data from the 2013 National Census on Higher Education (Instituto Nacional de Estudos e Pesquisas Educacionais Anísio Teixeira [INEP], 2013) reveal that $26.5 \%$ of matriculations in higher education are in public HEIs and $73.5 \%$ are in private HEIs. The greater participation of professors from public HEIs in the study may be explained, among other aspects, by the ease of access to the professors' emails.

With the aim of identifying possible biases derived from the predominantly public HEI sample, difference of means tests between the satisfaction indices were carried out; however, no statistically significant differences were found between the satisfaction levels of public and private HEI professors.

\subsection{General Satisfaction among Professors}

With regards to satisfaction among the accounting professors, the participants had to attribute answers based on a scale of 1 to 10 points, in which answers close to level 1 meant the respondent disagreed with the statement and answers close to 10 meant they agreed with the statement. In order to carry out the comparisons between proportions test, answers from 1 to 5 were divided into proportion 1 (P1), corresponding to disagreement with the statement, and those from 6 to 10 were divided into proportion 2 (P2), indicating agreement with the statement. Table 2 presents the results obtained. 
Table 2 General satisfaction among the professors

\begin{tabular}{llcccc}
\hline Variables & \multicolumn{1}{c}{ Questions } & P1 (n) & P2 (n) & P & Decision \\
\hline Satisfaction 1 & I like my profession. & $0.0484(31)$ & $0.9516(610)$ & $<0.000$ & P1 $<$ P2 \\
\hline Satisfaction 2 & In general, I feel satisfied in my teaching job. & $0.0655(42)$ & $0.9345(599)$ & $<0.000$ & P1 $1<$ P2 \\
\hline Dissatisfaction 1 & Sometimes I feel discouraged with my profession. & $0.5632(361)$ & $0.4368(280)$ & $<0.000$ & P1 $>$ P2 \\
\hline Dissatisfaction 2 & If it were possible, I would change job. & $0.8596(551)$ & $0.1404(90)$ & $<0.001$ & P1 $>$ P2 \\
\hline
\end{tabular}

$P=$ proportion .

Source: Developed by the authors.

At a 5\% level of significance and using the comparisons between proportions test, when the professors where questioned in relation to "liking the profession", the answers were almost totally concentrated in proportion 2 , showing that most professors like the profession. When questioned in relation to "feeling satisfied with the job", more than $90 \%$ of the respondents reported being satisfied with their teaching career.

These results provide the first research evidence that accounting professors are predominantly satisfied with the profession, thus converging with studies carried out in higher education in previous investigations (Ferreira, 2011; Ferreira, Machado \& Gouveia, 2012; Moretti, 2010), which identified positive satisfaction among professors, unlike the study carried out in elementary education, which indicates dissatisfaction among teaching staff (Pedro \& Peixoto, 2006).

At a 5\% level of significance, using the comparisons of proportions test, when the professors were questioned regarding "feeling discouraged by the profession", $56 \%$ (361 professors) disagree with this statement, confirming the trend identified in the previous question. However, it should be mentioned that $44 \%$ of the professors questioned sometimes feel discouraged with the profession, indicating that even among those who feed satisfied with teaching, moments of discouragement exist.

Finally, when questioned regarding "changing job", only $14 \%$ of those investigated (90 professors) said they would change. It is interesting to observe that $61 \%$ of these professors were male, $39 \%$ doctors and $44 \%$ masters, $70 \%$ did not carry out any other activity besides teaching, $68 \%$ were in the third stage of the life cycle, and $83 \%$ were linked to public institutions. In summary, the profile of the professor who would change job is: male, in the middle of the career, with a title, dedicated exclusively to teaching, and from a public institution.

It is noteworthy that the proportion of dissatisfaction with regards to the profession among accounting professors is much lower than the proportion related to satisfaction. This result is coherent with the responses to the first two questions and confirms the tendency for satisfaction among the professors investigated.

To complete the analysis, the general level of satisfaction among professors throughout the career stages proposed by Huberman (2000) was investigated. Figures 3, 4, 5, and 6 present the questions on general satisfaction in relation to the career stages, as well as the p-values from the chi-squared test, which verify whether the level of satisfaction depends on stage.

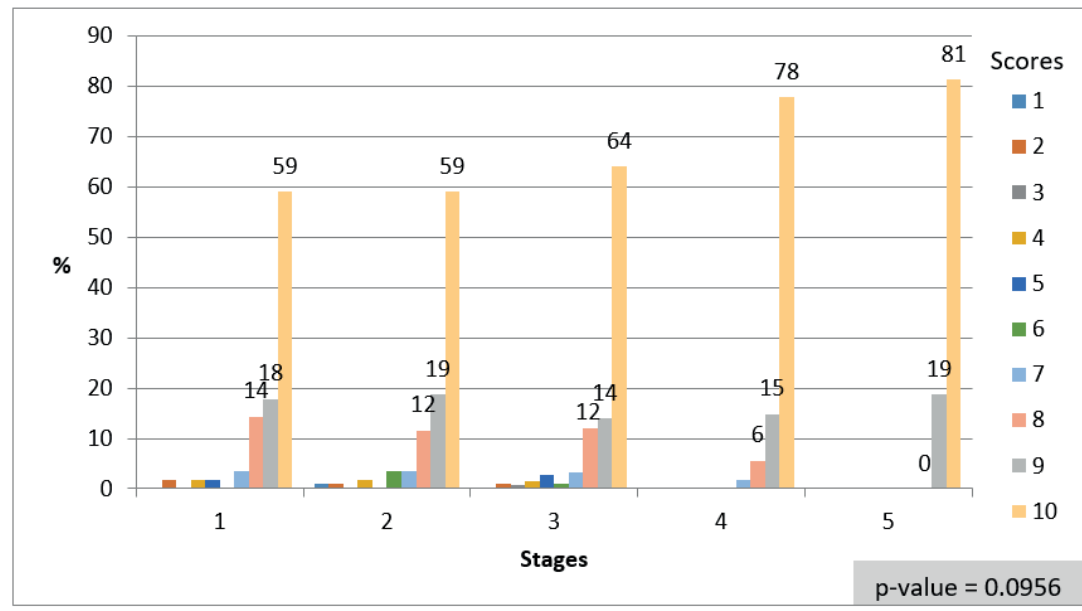

Figure 3 I like my profession

Source: Developed by the authors. 
It can be observed that approximately $80 \%$ of the professors in stages 1,2 , and 3 , when asked whether they like the profession, attributed scores of 9 or 10, indicating that they in fact like the profession. In the subsequent stages, this percentage rises even more. In stage 4 , for example, $83 \%$ of the professors attributed scores of 9 or 10 , and in stage 5 , all of the professors gave a score of 9 or 10 . The chi-squared test, using a $10 \%$ level of significance, shows evidence that "liking" the profession increases with the professors' time of experience $(\mathrm{p}=0.0956)$.
It can be noted, in Figure 4, that $64 \%$ of the professors in stage 1 attributed higher satisfaction scores (9 or 10) and that there was a tendency for growth over the course of the other career stages. In the last stage (5), $93 \%$ of the sample chose scores of 9 or 10 with regards to job satisfaction. The chi-squared test, using a $10 \%$ level of significance, shows evidence that as professors acquire more experience in the profession, their satisfaction increases $(\mathrm{p}=0.0854)$.

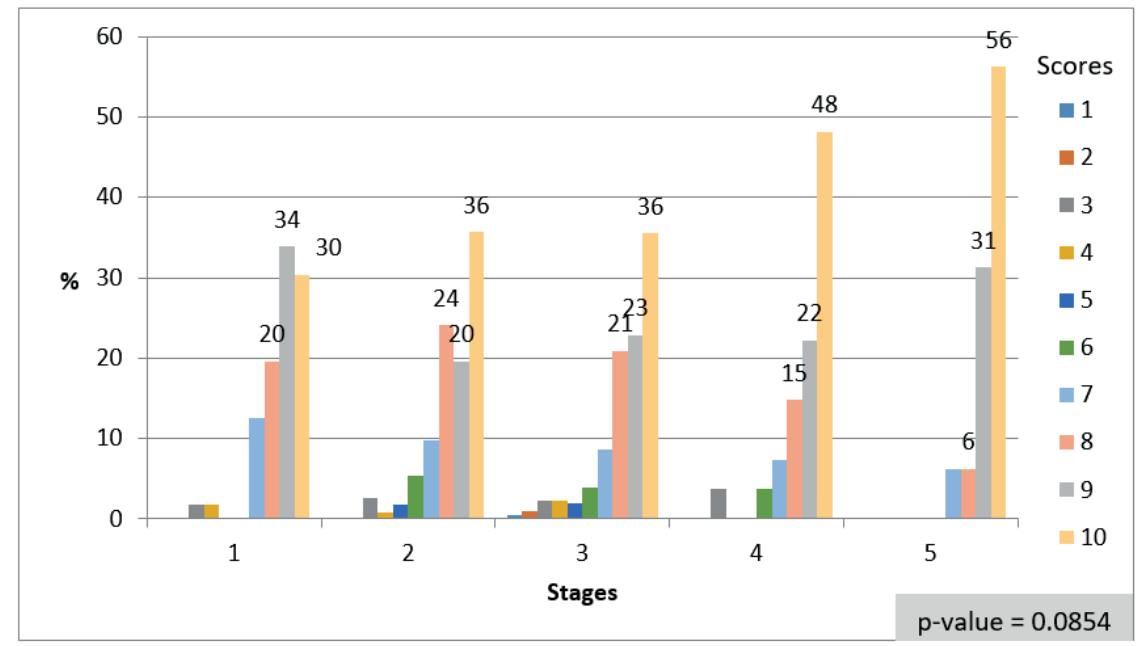

Figure 4 I feel satisfied with the profession

Source: Developed by the authors.

The professors were also investigated with regards to "feeling discouraged with the profession". Figure 5 presents the results.

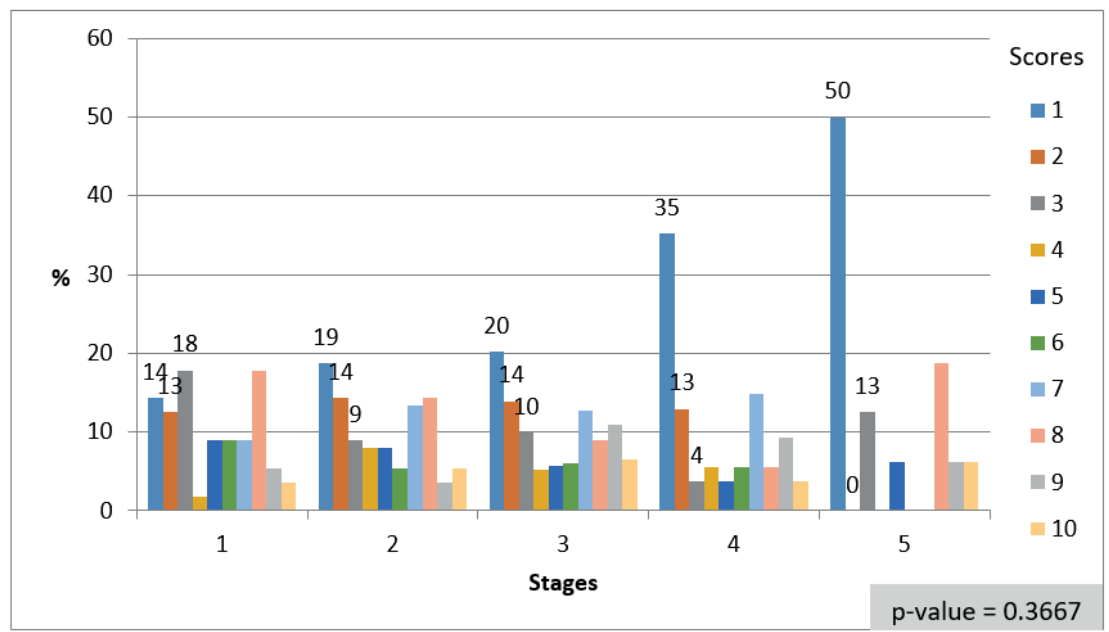

Figure 5. I feel discouraged with the profession

Source: Developed by the authors. 
Unlike figures 3 and 4, in Figure 5 an increase in lower scores can be seen over the course of the stages, especially score 1 , showing that, at the beginning of the career, there is more disappointment as a result of the difficulties. In this case, using the chi-squared test at a $10 \%$ level of significance shows no evidence of a connection between discouraged professors and time in teaching ( $\mathrm{p}$ $=0.3667$ ).

The last question investigated, "if I could, I would

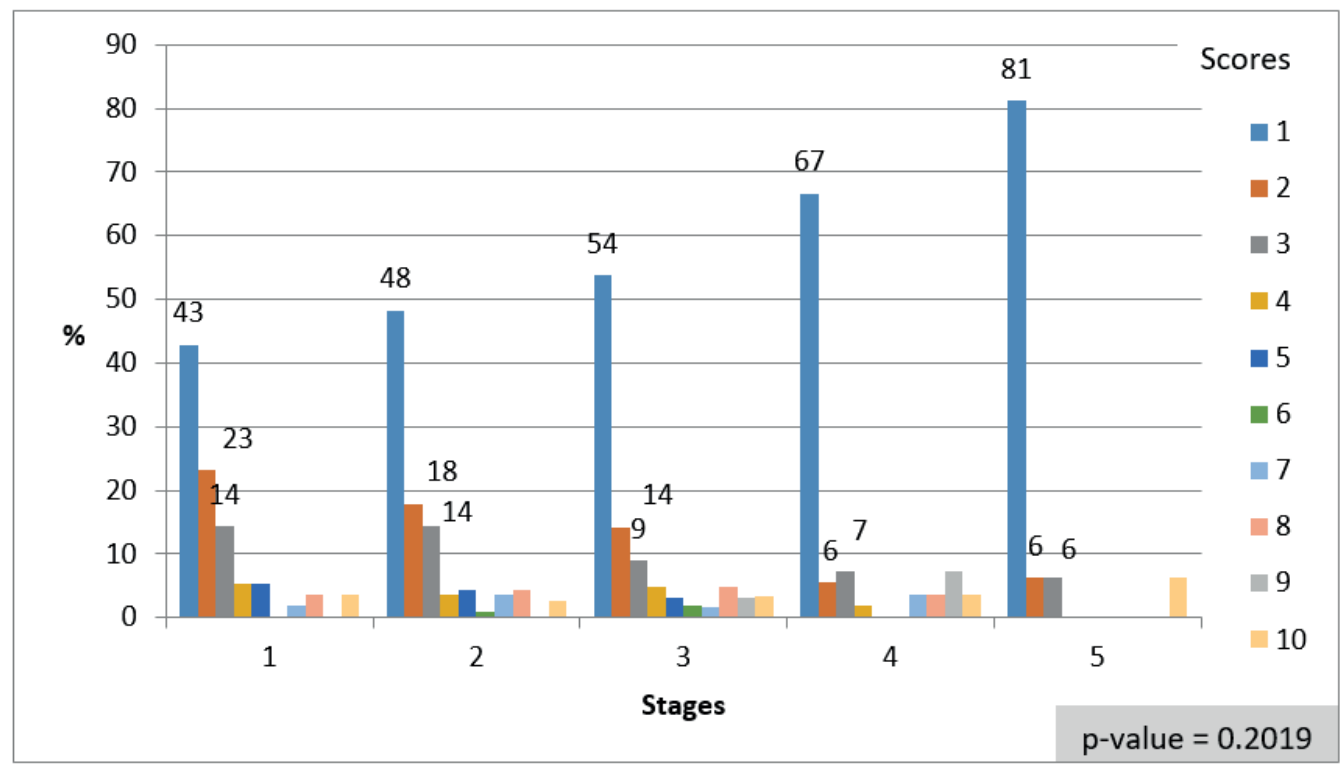

Figure 6 If I could, I would change profession

Source: Developed by the authors.

change profession", is presented in Figure 6.

From Figure 6 it is possible to see that $66 \%$ of the professors who find themselves in the first two stages disagree with the statement, having indicated scores 1 or 2. As for the professors in the other stages, more than half chose to disagree with the statement, and in the last stage (5), $93 \%$ totally disagree with the statement. However, using the chi-squared test at a $10 \%$ level of significance shows no evidence of a connection between the statement and time in teaching.

Thus, with regards to satisfaction, the results identified suggest that it is positive and rises over the course of the career stages. Even though the studies from Huberman $(1989,2000)$ suggest that there can be satisfaction and dissatisfaction in practically all stages of the career - for example, in the first stage, discovery/ enthusiasm vs. reality shock, in the third, diversification vs. questioning, in the fourth, serene distancing vs. conservatism, and in the fifth stage, serene divestment vs. bitter divestment - it must be highlighted that, in the more advanced stages of the career, teaching professionals undoubtedly take into account the investment already made in the career $v i s-\grave{a}$-vis the opportunities for change at this time. It can be said that these phases involve a certain settling or acceptance, "of accepting as such" (Huberman,
2000, p. 50).

\subsection{Factors Related to Job Satisfaction}

In the third section of the questionnaire, the professors are presented with 25 questions for which they should inform their level of agreement, on a scale of 1 to 10 points. Answers close to 1 mean "it does not satisfy me" and those close to 10 mean "it satisfies me completely".

To simplify the number of items composing the questionnaire, EFA analysis was carried out. According to Fávero et al. (2009), this test aims to analyze the connection between each variable and a factor and how much this factor can explain the results found in a sample. By carrying out factor analysis, a result to the Kaiser Meyer Olkin (KMO) test of 0.92 was found. Figueiredo and Silva (2010) mention that this test can vary between 0 and 1 and that the closer to 1, the better; in other words, the KMO obtained in this study satisfied the test.

According to Table 3, five factors are created, which explain $62.77 \%$ of the total variance in the data. It is also observed that all the items obtained factor loads greater than 0.40 (Fávero et al., 2009). Moreover, according to 
Table 3 Factor Analysis (varimax rotation)

\begin{tabular}{|c|c|c|c|c|c|}
\hline \multirow{2}{*}{ Questions } & \multicolumn{5}{|c|}{ Mean } \\
\hline & Factor 1 & Factor 2 & Factor 3 & Factor 4 & Factor 5 \\
\hline 6. Functioning/communication between the various parts of the institution & 0.777 & & & & \\
\hline 7. Professional relationships with other professors & 0.802 & & & & \\
\hline 8. Autonomy in implementing the programs in their activities & 0.468 & & & & \\
\hline 9. Material conditions in the workplace & 0.620 & & & & \\
\hline 11. Personal relationships with other professors & 0.751 & & & & \\
\hline 17. Challenges existing in this profession & 0.404 & & & & \\
\hline 18. Support from the institution in solving problems & 0.666 & & & & \\
\hline 24. Relationship with the governing bodies of the institution & 0.708 & & & & \\
\hline 3. Social status of professors & & 0.434 & & & \\
\hline 10. Professor salary & & 0.683 & & & \\
\hline 12. Processes for career progression & & 0.642 & & & \\
\hline 13. Responsibilities required of professors & & 0.422 & & & \\
\hline 14. Social recognition & & 0.744 & & & \\
\hline 21. Attitude of society towards professors & & 0.730 & & & \\
\hline 16. Quantity of work & & & 0.421 & & \\
\hline 19. Security/stability at work & & & 0.575 & & \\
\hline 22. Duration of vacation period(s) & & & 0.744 & & \\
\hline 23. Flexibility in the work schedule & & & 0.789 & & \\
\hline 25. Time available for family/friends & & & 0.737 & & \\
\hline 4. Attention/interest of students in the classroom & & & & 0.814 & \\
\hline 15. Student study at home/academic preparation of students & & & & 0.691 & \\
\hline 20. Student behavior/discipline in the classroom & & & & 0.745 & \\
\hline 1. Working directly with students & & & & & 0.799 \\
\hline 2. Level of personal fulfillment & & & & & 0.783 \\
\hline 5. Relationship with students & & & & & 0.543 \\
\hline Eigenvalues & 10.02 & 1.81 & 1.48 & 1.27 & 1.11 \\
\hline$\%$ of explained variance & 40.06 & 7.24 & 5.93 & 5.09 & 4.46 \\
\hline$\%$ of cumulative variance & 40.06 & 47.30 & 53.22 & 58.31 & 62.77 \\
\hline Cronbach's alpha & 0.892 & 0.838 & 0.769 & 0.821 & 0.715 \\
\hline
\end{tabular}

Source: Developed by the authors.

Hair et al. (2005), the lowest limit generally accepted for the Cronbach alpha is 0.70 , which was also reached.

The factors evaluated in this study are similar to those assessed by Pedro and Peixoto (2006):

Factor 1 - interpersonal and institutional relationships, which grouped the items related to the professor's relationship with the teaching institution;

Factor 2 - sociopolitical, which involved the items related to salary and professional questions;

Factor 3 - working conditions, with item related to the teaching work conditions;

Factor 4 - students, which contemplates the items related to questions concerning the students;

Factor 5 - personal fulfillment, which grouped items related to the teaching work and the relationship with students.

The first three factors $(1,2$, and 3$)$ contain items related to the hygienic factors, which are extrinsic, derive from dissatisfaction and over which employees have no control. The lack of these factors can demotivate workers, as described in theory from Herzberg (1987). As for the last two factors, these contemplated items related to the motivational factors addressed by Herzberg (1987). These factors are intrinsic, create satisfaction among employees, and are directly related to the roles carried out by employees.

The next step is to analyze whether the factors assessed are in fact associated with satisfaction among 
Table 4 Test of correlation between the motivational factors and level of satisfaction among professors

\begin{tabular}{|c|c|c|c|c|c|}
\hline \multirow{2}{*}{ Satisfaction } & \multicolumn{5}{|c|}{ Spearman Correlation } \\
\hline & Factor 1 & Factor 2 & Factor 3 & Factor 4 & Factor 5 \\
\hline I like my profession & 0.257 & 0.125 & 0.142 & 0.121 & 0.493 \\
\hline $\mathrm{p}$ & 0.000 & 0.002 & 0.000 & 0.000 & 0.002 \\
\hline In general, I feel satisfied in my teaching job & 0.313 & 0.201 & 0.195 & 0.188 & 0.420 \\
\hline $\mathrm{p}$ & 0.000 & 0.000 & 0.000 & 0.000 & 0.000 \\
\hline \multicolumn{6}{|l|}{ Dissatisfaction } \\
\hline Sometimes I feel discouraged with my profession & -0.166 & -0.164 & -0.075 & -0.212 & -0.184 \\
\hline $\mathrm{p}$ & 0.000 & 0.000 & 0.057 & 0.000 & 0.000 \\
\hline If it were possible, I would change job & -0.169 & -0.114 & -0.127 & -0.120 & -0.338 \\
\hline $\mathrm{p}$ & 0.000 & 0.004 & 0.001 & 0.002 & 0.000 \\
\hline
\end{tabular}

Source: Developed by the authors.

the respondents. The Spearman correlation test was thus carried out. The results are presented in Table 4 .

From Table 4, it can be noted that there is a positive and significant correlation between all of the factors found in the study and the two questions related to general satisfaction among the professors, using a 5\% level of significance. Similarly, a negative and significant correlation is identified between the five factors and the two questions related to dissatisfaction, also at a level of $5 \%$. These results show that these factors are related with the levels of satisfaction among accounting course professors and support the results obtained previously (Pedro, 2011; Pedro \& Peixoto, 2006). In other words, in the field of accounting courses in Brazil, the assumptions of the two-factor theory remain valid, since both the hygienic factors, which are extrinsic and prevent dissatisfaction, and the motivational factors, which are intrinsic and create satisfaction, are significantly correlated with satisfaction among the professors.

The factors that presented the highest coefficients of correlation were factor 5 (personal fulfillment) and factor 1 (interpersonal and institutional relationships). The former is linked to the motivational factors and the latter to the hygienic factors. This result partially converges with those of Pedro and Peixoto (2006), who in their study presented that the interpersonal and institutional relationships factor is the one that is most associated with professor satisfaction. The result also supports what is proposed by the two-factor theory from Herzberg (1987), according to which motivational factors, such as personal fulfillment, are positively associated with satisfaction.

When the questions are inverted, or rather, when the factors associated with dissatisfaction are analyzed, the coefficients are all negative. The factors that are most correlated are factor 4 (students), factor 5 (personal fulfillment), and factor 1 (interpersonal and institutional relationships), with the first two being linked to the motivational factors and the latter to the hygienic factors. This means that the less fulfilled the professor is, the more dissatisfied.

Considering that previous studies have already identified a connection between professor satisfaction and academic performance (Taveira \& Silva, 2015), it becomes important for educational managers to pay attention to the five factors mentioned above, since all of them presented significant correlations with the questions on satisfaction and dissatisfaction, notably the factors that presented the highest coefficients (F1 and F5).

Tests were also carried out involving the correlation between the questions related to satisfaction and dissatisfaction and the control variables: gender, life cycle stage, region, public and private institution, age, and title of professor; however, none of these presented any level of significance.

\subsection{Feelings Experienced by the Professors}

Figure 7 presents the proportion of positive and negative feelings mentioned by the professors in the sample investigated involving teaching accounting. 


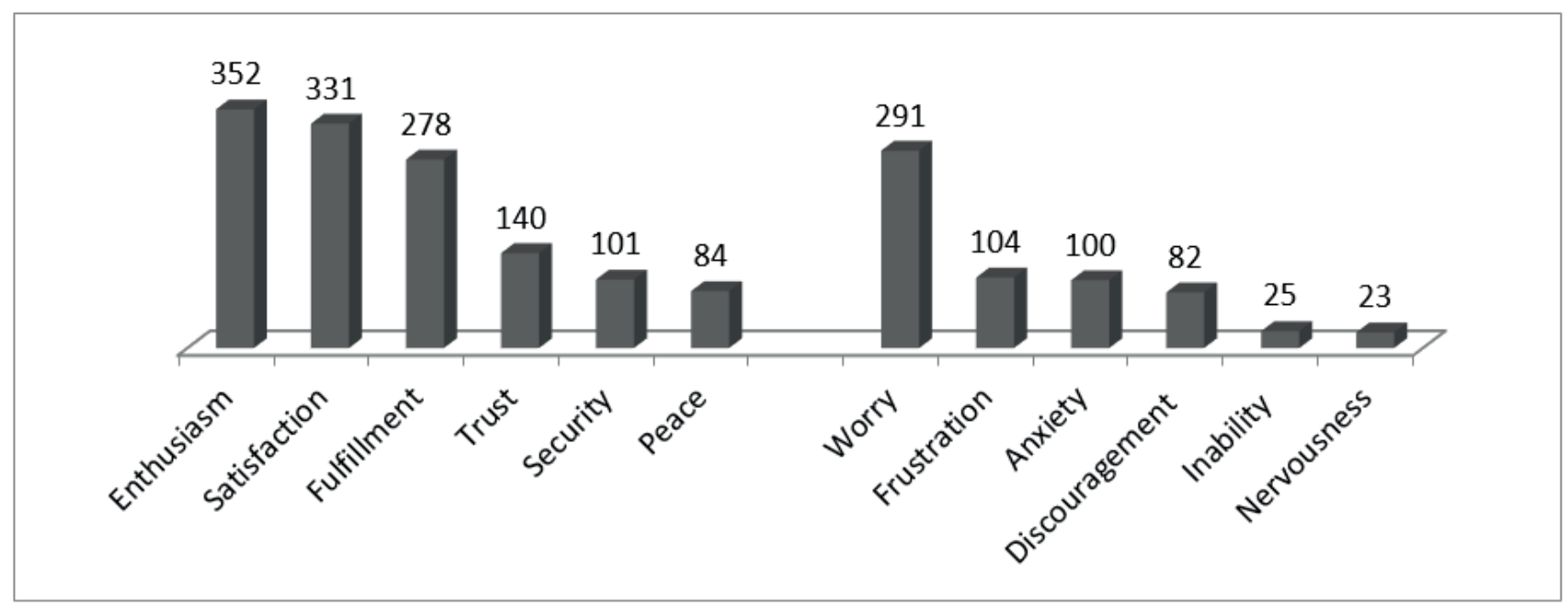

Figure 7 Feelings experienced by the sample Source: Developed by the authors.

It can be noted that the proportion of positive feelings is visibly greater than the negative ones and only the feeling of "worry" stands out among the negatives. The feelings of frustration, anxiety, and discouragement are also relevant, but appear in smaller proportions than worry.

It is also interesting to observe that the three most representative positive feelings (enthusiasm, satisfaction, and fulfillment) were numerically higher in the private institutions than in the public ones $(19.8 \%, 17.4 \%$, and $15.7 \%$ versus $17.5 \%, 17.3 \%$, and $14.1 \%$, respectively). Moreover, the feeling of worry also appeared with more intensity in the public institutions than in the private ones (15.9\% and $13.8 \%$, respectively).

Table 5 presents the test of the proportion of positive versus negative feelings reported by the 641 professors composing the sample.

Table 5 Feelings experienced

\begin{tabular}{ccc}
\hline Feelings & Proportion & p \\
\hline Positive & 0.6729 & $<0.000$ \\
\hline Negative & 0.3271 & \\
\hline
\end{tabular}

Source: Developed by the authors.

At a 5\% level of significance, using the comparisons of proportions test, the results confirm the prevalence of satisfaction among the professors studied, since the most expressive feelings are positive (67.3\%). The negative feelings, which refer to job dissatisfaction, were chosen less by the professors (32.7\%). These results diverge from those found in the study from Pedro and Peixoto (2006) carried out in Portugal and involving elementary education teachers, according to which the negative feelings are among the most mentioned by the teachers in the sample: nervousness (39.7\%), worry (34.2\%), and security (32.9\%).

In summary, the results found in relation to the level of satisfaction among the professors, as well as its evolution throughout their careers, the results from the tests of correlation between the factors assessed in the factor analysis and the level of satisfaction, as well as the analysis of the positive and negative feelings experienced by the professors, all point in the same direction: satisfaction among accounting professors in Brazil prevails over dissatisfaction.

It is important to highlight that among the unsatisfied professors the following characteristics predominate: male, in the middle of the career, with a title, dedicated exclusively to teaching, and from a public institution. Moreover, it can be noted that, with regards to satisfaction, these professors attributed visibly lower scores than the others for the following items: support from the institution in resolving problems, responsibility demanded of professors, social recognition, attitude of society towards professors, time available for family/ friends, and level of personal fulfillment. 
The different results obtained in the study indicate the prevalence of general satisfaction among accounting professors, as the majority "like the profession" and, "in general, feel satisfied with the profession". Some studies indicate that teaching staff in different areas, such as nursing, business, and elementary education, are also satisfied with their professions (Ferreira, 2011; Ferreira et al., 2012; Moretti, 2010).

Observing the stages in a teaching career, the study identified that, as the number of years of experience increases, there is an increase in the satisfaction perceived by the professors (figures 3 and 5), given that the first phase has lower levels of satisfaction and the last phase presents the highest levels. The literature already indicates that the first phase is critical and that it requires care. According to Huberman (2000), the problems are greater in this phase, due to teaching professionals' inexperience and lack of preparation.

This tendency is aligned with the two-factor theory from Herzberg (1987), since as time passes the same professors acquire more experience and become more confident in facing the problems that originate from teaching, which can lead to them being more satisfied.

The correlation analysis indicated that all the factors generated by the EFA are significantly correlated with the questions in the study related to general satisfaction. Factor 5 (personal fulfillment), which is associated with the motivational factors, is the one that correlates the most with job satisfaction. This indicates that, for the professors investigated, personal fulfillment is very important for satisfaction in teaching. This finding converges with that found in the theory from Herzberg (1987), in which the motivational factors increase teacher satisfaction.

Another piece of evidence that satisfaction among professors is greater than dissatisfaction involves the analysis of positive and negative feelings experienced by the professors in the profession. At a 5\% level of significance, using the comparisons of proportions test, it was possible to identify that the most expressive feelings are positive ones (67.3\%). As for the negative feelings, which reflect job dissatisfaction, these were the least chosen by the professors (32.7\%). Here, it is important to highlight that more than $70 \%$ of the sample was in more advanced stages of the career (stages 3, 4, and 5).

These results show that, despite accounting teaching in Brazil undergoing significant changes due to the increase in matriculations and adhesion to international accounting standards, satisfaction with the profession prevails among the teaching staff. In other words, despite the problems, accounting teaching seems attractive.

The results also show an increase in the presence of females in recent years, especially among new arrivals to the profession. This fact, together with the increase in professors with a strict sensu qualification, indicates a change in the profile of accounting professors in the near future.

This paper contributes by adding to the studies involving job satisfaction among professors in the area of accounting, given that, in Brazil, such investigations are still rare. Moreover, by identifying that the most critical stage for professor dissatisfaction is the initial one, it encourages new studies regarding entry into the teaching career, in order to better explain the issues that affect new arrivals to the profession.

Also worth mentioning is the importance of educational managers continuously evaluating the factors related to professor satisfaction, as the literature already presents indications that professor satisfaction may be related to student academic performance (Taveira \& Silva, 2015). Accounting courses have consistently presented low indices in the ENADE and in the CFC Sufficiency Exam.

Finally, the limitations of this study should be highlighted. It is emphasized that the use of the life stages proposed by Huberman (1989) may not portray exactly the professional life cycle of accounting professors in Brazil. The sample, although expressive, is predominantly comprised of public HEIs and its representativeness of Brazilian accounting professors is not known exactly, due to the absence of such information. It is also highlighted that there may be some bias originating from the lack of replies, as individuals with lower levels of satisfaction with the profession may be less interested in studies of this nature.

In order to complement this study, a qualitative analysis is proposed involving accounting course professors, in order to verify which variables in fact make them more or less satisfied, thus leading to a broader study being carried out. Another question involves expanding the study to the area of business and thus widening the analysis. Whether satisfaction among professors influences accounting student academic performance could also be investigated. 


\section{REFERENCES}

Alves, F. C. (1991). Estudo da satisfação/insatisfação dos professores efectivos do $3^{\circ}$ ciclo do ensino básico e do ensino secundário do distrito de Bragança (Master's Degree). Universidade de Lisboa, Lisboa.

Alvies, F. C. (1994). (In)satisfação docente. Revista Portuguesa de Pedagogia, 27, 29-60.

Anitha, R. (2011). A study on job satisfaction of paper mill employees with special reference to Udumalpet and PalaniTaluk. Journal of Management and Science, 1(1), 36-47.

Araújo, T. S., Lima, F. D. C., Oliveira, A. C. L., \& Miranda, G. J. (2015). Problemas percebidos no exercício da docência em contabilidade. Revista Contabilidade \& Finanças, 26(67), 93105.

Assunção, R. R., Domingos, S. R. M., Cabral, A. C. A., Santos, S. M., \& Pessoa, M. N. M. (2014). Satīsfação e comprometimento organizacional afetivo: um estudo com docentes universitários do curso de ciências contábeis. Revista de Administração da UFSM, 7(3), 453-468.

Bergamini, C. W. (1997). Motivação nas organizações (4a. ed.). São Paulo, SP: Atlas.

Biase, N. G., \& Ferreira, D. F. (2009). Comparações múltiplas e testes simultâneos para parâmetros binomiais de $\mathrm{k}$ populações independentes. Revista Brasileira de Biometria, 27, 301-323.

Bohrer, R. S. (1981). Motivação: abordagem crítica da teoria de Maslow pela propaganda. Revista Administração de Empresas, 21(4), 43-47.

Brasil. (1996). Lei no 9.394, de 20 de dezembro de 1996. Estabelece as diretrizes e bases da educação nacional. Brasília, DF: Diário Oficial da União. Retrieved from http://www.planalto.gov.br/ ccivil_03/leis/19394.htm.

Conselho Federal de Contabilidade. (2015). Exame de Suficiência: Resultado do $1^{\circ}$ Exame de 2015 é publicado no DOU. Jornal do CFC, 18(126). Retrieved from http://portalcfc.org.br/ wordpress/wp-content/uploads/2013/01/jornal126_abr_mai_ FIM_web.pdf.

Fávero, L. P. L., Belfiore, P. P., Silva, F. L., \& Chan, B. L. (2009). Análise de dados: modelagem multivariada para tomada de decisões. Rio de Janeiro, RJ: Elsevier.

Ferreira, A. C: M. (2011). Satisfação no trabalho de docentes de uma instituição pública de ensino superior: reflexos na qualidade de vida (Master's Degree). Universidade Federal de Goiás, Goiânia.

Ferreira, A., Demutti, C. M., \& Gimenez, P. E. O. (2010). A teoria das necessidades de Maslow: a influência do nível educacional sobre a sua percepção no ambiente de trabalho. Anais do Seminários de Administração, São Paulo, SP, Brasil, 13.

Ferreira, J. B., Machado, M. L., \& Gouveia,.O. (2012). A (in) satisfação dos académicos no ensino superior. Educação, Sociedade \& Culturas, 37, 129-139.

Ferreira, M. A. M. (2008). Ciclo de vida, desenvolvimento profissional e gestão escolar - uma abordagem biográfica (Master's Degree). Universidade Aberta, Lisboa.

Figueiredo, D. B., Filho, \& Silva, J. A., Jr. (2010). Visão além do alcance: uma introdução à análise fatorial: Opinião Pública, 16(1), 160-185.
Frase, L. E., \& Sorenson. L. (1992). Teacher motivation and satisfaction: impact on participatory management. NASSP Bulletin, 76, 37-43.

Freitas, M. F. P. (2011). Satisfação profissional dos enfermeiros especialistas (Master's Degree). Instituto Politécnico de Viseu, Viseu.

Gall, M. D., Gall, J. P., \& Borg, W. R. (2007). Educational research: an introduction (8a. ed.). Boston, MA: Pearson.

Gonçalves, J. A. (1995). A carreira das professoras do ensino prịmário. In: Nóvoa, A. (Org.). Vida de professores. Porto: Porto Editora.

Gonçalves, J. A. (2009). Desenvolvimento profissional e carreira docente - fases da carreira, currículo e supervisão. Sísifo: Revista de Ciências da Educação, 8, 23-36.

Gursel, M., Sunbul, A. M., \& Sari, H. (2002). An analysis of burnout and job satisfaction between Turkish head teachers and teachers. European Journal of Psychology of Education, 17, 35-45.

Hair, J. F., Jr., Anderson, R. E., Tatham, R. L.,\& Black, W. C. (2005). Análise multivariada de dados (5a. ed.). Porto Alegre, RS: Bookman.

Hering, S. Q. (1996). Motivação dos quadros operacionais para a qualidade sob o enfoque da liderança situacional (Master's Degree). Universidade Federal de Santa Catarina, Florianópolis.

Herzberg, F. (1987). One more time: how do you motivate employees? Harvard Business Review, Watertown, USA: Retrieved from http://synchronit.com/downloads/freebooks/ herzberg.pdf.

Huberman, M. (1989). Le cycle de vie professionnelle des enseignants secondaires: résumé d'une recherche démentielle. Genève: Cahiers de la Section des Sciences de l'Education: pratiques et théorie, 54 .

Huberman, M. (2000). O ciclo de vida profissional dos professores. In: Nóvoa, A. (Org). Vida de professores (2a. ed.). Porto: Porto Editora.

Instituto Nacional de Estudos e Pesquisas Educacionais Anísio Teixeira. (2013). Censo do Ensino Superior. Retrieved from http://download.inep.gov.br/educacao_superior/censo_ superior/apresentacao/2014/coletiva_censo_superior_2013. pdf.

Jesus, S. N. (1993). A motivação dos professores: estudo exploratório sobre a influência da formação educacional e da prática profissional. Jornal de Psicologia, 11, 27-30.

Jesus, S. N. (1995). A análise da motivação para a profissão docente segundo o modelo da discrepância motivacional: um estudo preliminar. Revista Portuguesa de Educação, 8, 163-180.

Jesus, S. N., Abreu, M. V., Santos, E. J. R., \& Pereira, A. M. S. (1992). Estudo dos' factores de mal-estar na profissão docente. Revista Psychologica, 8, 51-60.

Jesus, S. N., \& Santos, J. C. V. (2004). Desenvolvimento profissional e motivação dos professores. Revista Educação, 1 , 39-54. 
Lima, F, D. C., Oliveira, A. C. L., Araújo, T. S., \& Miranda, G. J. (2015). O choque com a realidade: dormi contador e acordei professor.., Revista Electrónica Iberoamericana Sobre Calidad, Eficacia y Cambio en Educación, 13, 49-67.

Locke E. A. (1976). The nature and causes of job satisfaction. In: Dunnette, M. D. (1976). Handbook of industrial and organizational psychology. Chicago (IL): Rand McNally, p. 1297-349.

Martins, G. A., \& Theóphilo, C. R. (2007). Metodologia da investigação científica para ciências sociais aplicadas. São Paulo, SP: Atlas.

Maslow, A. H. (1943). A theory of human motivation. Revista Psychologica, 50, 370-396.

Megginson, L. C., Mosley, D. C., \& Pietri, P. H., Jr. (1986). Administração: conceitos e aplicações. Tradução de Auriphebo Berrance Simões. São Paulo, SP: Harba.

Moretti, G. J. S. (2010). O perfil e a satisfação no trabalho dos professores dos cursos de graduação em Administração das instituições de cursos superiores privadas da cidade de Ribeirão Preto-SP (Master's Degree). Universidade de São Paulo, Ribeirão Preto.

Pedro, N. (2011). Auto-eficácia e satisfação profissional dos professores: colocando os construtos em relação num grupo de professores do ensino básico e secundário. Revista de Educação, Lisboa, Portugal, 18(1), 23-47.

Pedro, N., \& Peixoto, F. (2006). Satisfação profissional e autoestima em professores dos $2^{\circ}$ e $3^{\circ}$ ciclos do ensino básico. Revista Análise Psicológica, 24(2), 247-262.

Pinto, F. C. (1996). Mal-estar na docência: o fundo da questão. Revista O Professor, 50(3), 3-8.
Portal Brasil. (2014). Educação: ensino superior registra mais 7,3 milhões de estudantes. Retrieved from http://www.brasil.gov. br/educacao/2014/09/ensino-superior-registra-mais-de-7-3milhoes-de-estudantes.

Ramos, S. I. V. (2009). (In)satisfação e stress docente. Estudo Geral, [3]1-41. Retrieved on March 2, 2016, from https:// estudogeral.sib.uc.pt/handle/10316/8522.

Sánchez, A. M., \& García, J. L. (1997). El clima de las instituciones educativas y la satisfacción laboral de los profesores. Revista de la Escuela de Ciencias de la Educación, 176, 419-436.

Seco, G. M. S. B. (2000). A satisfação na actividade docente (Doctoral Thesis). Universidade de Coimbra, Coimbra.

Siegel, S., \& Castellan, N. J. (1988). Nonparametric statistics for the behavioral sciences. New York, NY: McGraw-Hill.

Siqueira, M. M. M. (2008). Medidas do comportamento organizacional: ferramentas de diagnóstico de gestão. Porto Alegre, RS: Artmed.

Taveira, I. M. R., \& Silva, J. S. (2015). A relação entre a satisfação dos professores e o desempenho dos alunos de Macaé. Anais do Congresso Nacional de Administração e Contabilidade, Rio de Janeiro, RJ, Brasil, 6.

Traldi, M. T. F., \& Fiuza, G. D. (2012). Comprometimento, bemestar e satisfação dos professores de administração de uma universidade federal. Revista Eletrônica de Administração, 2, 290-316.

Veenman, S. (1984). Perceived Problems of Beginning Teachers. Review of Educational Research, Catholic University of Nijmegen, 54(2), 143-178.

\section{Correspondence address:}

Tamires Sousa Araújo

Universidade Federal de Uberlândia, Faculdade de Ciências Contábeis

Av. João Naves de Ávila, 2121 - Bloco F - CEP: 38400-902

Campus Santa Mônica - Uberlândia-MG - Brasil

Email: tamiresousa124@hotmail.com 